\title{
Emerging treatments for advanced pancreatic cancer: clinical potential of albumin-bound paclitaxel
}

This article was published in the following Dove Press journal:

Gastrointestinal Cancer: Targets and Therapy

25 June 2014

Number of times this article has been viewed

\section{Elisa Fontana \\ Francesco Sclafani \\ David Cunningham}

Department of Medicine, The Royal Marsden NHS Foundation Trust, London and Surrey, UK
Correspondence: David Cunningham Department of Medicine, The Royal Marsden NHS Foundation Trust Hospital, Downs Road, Sutton, Surrey, SM2 5PT, UK

Tel +4420866I 3156

Fax +44 2086439414

Email david.cunningham@rmh.nhs.uk
Abstract: The management of pancreatic cancer has historically represented a major challenge for oncologists. The inherent aggressiveness of this tumor and the fibrotic features of the surrounding stromal tissue have significantly limited the impact of standard chemotherapy. Moreover, the paucity of available tumor tissue has hampered a better understanding of the biology of this disease as well as the development of new treatment strategies. Recently, the therapeutic landscape of metastatic pancreatic cancer has been enriched by two new combination regimens (FOLFIRINOX and gemcitabine-nab-paclitaxel) which have been demonstrated to improve the outcome in patients with good performance status. Moreover, the peritumoral stroma has been increasingly recognized as a potential therapeutic target for this disease, and several new agents targeting stromal components are currently under investigation. In this paper, we review the current treatment options for advanced pancreatic cancer, highlight the role of the peritumoral stroma, and discuss the clinical potential of nab-paclitaxel and antistromal treatment strategies.

Keywords: pancreatic cancer, nab-paclitaxel, stroma, SPARC

\section{Introduction}

Pancreatic cancer is the eighth most common malignant tumor in Europe, with 103,800 estimated new cancer cases in 2012, and is the fourth most common cause of cancer-related death. ${ }^{1}$ Cancer mortality predictions for the year 2013 show that pancreatic cancer remains the only major cancer type (alongside lung cancer in women) for which no improvement in mortality rate has been predicted. ${ }^{2}$

In the recent Cancer Statistics 2013 from the American Cancer Society, the 5-year overall survival rate for pancreatic cancer has been reported to be $6 \%$. ${ }^{3}$ This unfavorable outcome is largely due to the fact that, in most cases, patients are initially diagnosed with advanced disease. Approximately $40 \%$ of patients present with inoperable locally advanced tumors, while approximately $40 \%-45 \%$ have distant metastases at the time of diagnosis. ${ }^{4}$ In these circumstances, the 5 -year overall survival rates are $9 \%$ and $2 \%$, respectively. ${ }^{3}$ Only a minority of patients $(10 \%-20 \%)$ have resectable disease at presentation. However, even when the tumor is diagnosed at an early stage and is potentially amenable to radical surgery, the prognosis remains poor; only $22 \%$ of patients undergoing curative resection are still alive at 5 years, and the median survival is 23 months. ${ }^{5,6}$

The characteristics of pancreatic cancer have historically made the management of this tumor a major challenge. ${ }^{7}$ In particular, the deep and poorly accessible location of the tumor and the absence of specific and sensitive diagnostic tumor markers hamper 
early radiological detection and largely delay histological diagnosis. Moreover, the inherent low chemosensitivity of pancreatic adenocarcinoma cells coupled with difficult drug penetration through the surrounding peritumoral stromal tissue significantly limits the impact of standard cytotoxic chemotherapy agents.

Gemcitabine and fluoropyrimidines have represented the mainstay of palliative chemotherapy for locally advanced or metastatic pancreatic cancer. ${ }^{8-10}$ Although targeted therapies have largely failed in pancreatic cancer, ${ }^{11-13}$ new chemotherapy agents or combination chemotherapy treatments have recently proved to be effective in this setting and have significantly widened the therapeutic options for the disease. ${ }^{14-16}$ Moreover, the pancreatic stroma has increasingly been recognized as a key component of the tumor-drug interaction process and emerged as an attractive therapeutic target for pancreatic cancer. ${ }^{17}$

In this paper, we review the role of the pancreatic tumor stroma and the emerging treatment options for patients with advanced disease. In particular, we focus on the clinical potential of nanoparticle albumin-bound (nab)-paclitaxel and its role within the evolving therapeutic landscape of pancreatic cancer.

\section{Peritumoral stroma: hallmark of pancreatic cancer and potential therapeutic target}

The desmoplastic nature of the tumor microenvironment is probably the most important hallmark of pancreatic cancer. The tumor stroma is a complex structure that accounts for most of the tumor bulk and largely influences the disorganized tumor vasculature, low blood microvessel density, and hypoxic microenvironment surrounding pancreatic cancer. ${ }^{18}$ Given the large amount of extracellular fibrotic tissue, the stroma represents a mechanical barrier, which limits the effective delivery of drugs to the tumor cells and ultimately affects the efficacy of treatment. ${ }^{19}$ More interestingly, it also represents a highly dynamic structure that, through the interaction between tumor and stromal cells and the autocrine or paracrine secretion of cytokines, chemokines, and growth factors, modulates crucial processes including tumor progression, invasiveness, and metastases. ${ }^{20,21}$

The pancreatic tumor stroma is formed by extracellular matrix proteins, such as fibronectin, collagen I and III, hyaluronic acid, secreted protein acidic and rich in cysteine (SPARC), and cellular elements including pancreatic stellate cells, fibroblasts, macrophages, inflammatory cells, pericytes, and endothelial cells. ${ }^{22}$ The mechanisms underlying the development and remodeling of the stroma have not been fully elucidated. However, it is commonly recognized that pancreatic stellate cells play a central role in these processes. $^{23-25}$

Pancreatic stellate cells are a subtype of highly proliferating fibroblasts that are activated by oxidative stresses, and cytokine or growth factors produced by tumor cells or other stromal cells, including activin A, interleukin-1, interleukin-6, transforming growth factor beta-1, plateletderived growth factor, vascular endothelial growth factor, and fibroblast growth factor. ${ }^{26}$ Once activated, pancreatic stellate cells acquire a myofibroblast-like phenotype and produce major components of the peritumoral stroma, including collagen I, collagen III, and fibronectin.

Pancreatic tumor survival and growth may be promoted through different mechanisms secondary to activation of pancreatic stellate cells and the formation of stroma. ${ }^{27}$ It has been shown that the irregular production and deposition of extracellular matrix proteins may promote survival and migration of tumor cells. ${ }^{28,29}$ A reduced sensitivity to antitumoral agents has been reported when pancreatic tumor cells are attached to extracellular matrix proteins. ${ }^{30}$ Moreover, some studies suggest that pancreatic stellate cells can induce tumor proliferation by activating the Notch signaling pathway in pancreatic cancer cells. ${ }^{31}$

Pancreatic stellate cells also produce matrix metalloproteinases and tissue inhibitors of metalloproteinases, two regulators of matrix remodeling that lead to increased invasion and metastatic potential of pancreatic tumor cells by degrading basal membrane collagen. ${ }^{32,33}$ Interestingly, the close and dynamic interaction between pancreatic cancer cells and pancreatic stellate cells does not appear to be limited to the primary tumor but is maintained during the metastatic process. Studies have shown that pancreatic stellate cells migrate to the site of metastatic tumor alongside tumor cells, thus potentially reproducing in the metastases the same mechanisms of stroma formation and remodeling observed in the primary tumor. ${ }^{34}$

The activity of the stromal component in pancreatic cancer may also be a potential prognostic marker. Erkan et al analyzed the deposition of collagen and $\alpha$-smooth muscle actin, a marker of pancreatic stellate cell activity, in 233 tumor tissues from a prospectively registered database of pancreatic cancer patients who underwent surgery. They defined the activated stroma index as the ratio between the $\alpha$-smooth muscle actin-stained area and the collagen-stained area, and identified four major patterns of collagen deposition. Interestingly, patients with the lowest activated stroma index 
had the best median survival rate, while patients with the highest activated stroma index were found to have the worst outcome. Of note, the activated stroma index was shown to be an independent prognostic marker in multivariable survival analysis comparable with nodal status. ${ }^{35}$

In light of its key role in the mechanisms of oncogenesis, tumor growth, invasiveness, and metastases, the peritumoral stroma has recently emerged as an attractive therapeutic target for pancreatic cancer. The available evidence supporting the importance of dynamic stromal-epithelial interactions in the pancreatic tumor microenvironment suggests the hypothesis that targeting key components of the stroma may interfere with crucial tumor pathways and ultimately translate into significant antitumor activity. Moreover, combining targeted antistromal drugs with cytotoxic agents may also result in synergistic effects and increase the therapeutic potential of standard treatments. Several antistromal agents have been investigated in preclinical and early-stage clinical studies.

Sonic hedgehog pathway inhibitors ${ }^{36,37}$ are small molecules that have been shown to reduce the dense, fibrous peritumoral stroma, increase tumor perfusion, and enhance tumoral delivery of gemcitabine. ${ }^{38,39}$ However, despite the promising signals observed in preclinical and Phase I clinical studies, ${ }^{40,41}$ recent randomized Phase II trials investigating the addition of Sonic hedgehog to gemcitabine have failed to demonstrated a significant survival advantage. ${ }^{42,43}$ Trials investigating the addition of Sonic hedgehog inhibitors to other chemotherapy regimens including gemcitabine-nab-paclitaxel $(\mathrm{NCT} 01088815)^{44}$ or FOLFIRINOX (NCT01383538, ${ }^{45}$ NCT01485744 $)^{46}$ are currently ongoing.

Degradation of hyaluronic acid, an important component of the peritumoral stroma, has been shown to be a promising therapeutic approach for the treatment of pancreatic cancer. Moreover, the stromal changes resulting from enzymatic degradation of this glycosaminoglycan make this approach particularly interesting when used in association with standard chemotherapy. Indeed, administration of hyaluronidase has been reported to be associated with a reduction in interstitial pressure and an increase in diameter of tumor blood vessels, all changes that facilitate effective delivery of chemotherapy to pancreatic tumor cells. ${ }^{47}$ Promising activity has been observed with PEGPH20, a pegylated human recombinant $\mathrm{PH} 20$ hyaluronidase, in both preclinical and early clinical studies. ${ }^{48}$ The efficacy of a gemcitabine-PEGPH20 combination versus gemcitabine alone is now being evaluated in a Phase IB/II study in patients with previously untreated metastatic pancreatic cancer (NCT01453153). ${ }^{49}$
Another potentially interesting therapeutic target is represented by several key receptor tyrosine kinases, including vascular endothelial growth factor receptor, plateletderived growth factor receptor, and basic fibroblast growth factor receptor. Through either direct effects on pancreatic cancer cells or recruitment of endothelial cells and vascular smooth muscle cells into the stroma surrounding the tumor, these receptor tyrosine kinases promote tumor growth, control interstitial fluid pressure in the stroma, and facilitate development of metastases. ${ }^{50,51}$ Preclinical studies suggest that therapeutic inhibition of these receptor tyrosine kinases may result in a significant antitumor effect. ${ }^{52,53}$ The antitumor effects of these receptor tyrosine kinase inhibitors in vivo are currently under investigation (NCT01497392). ${ }^{54}$

\section{Current treatments options for metastatic pancreatic cancer}

In patients with metastatic disease, the major goals of treatment are symptom control, improvement of quality of life, and prolongation of survival. Historically, systemic chemotherapy, largely 5-fluorouracil-based, was shown to be superior over best supportive care in terms of psychological measures, quality of life, and overall survival. ${ }^{55,56}$ In 1997, a pivotal, randomized clinical trial $(n=126)$ showed that gemcitabine improved the clinical benefit rate $(23.8 \%$ versus $4.8 \%, P=0.0022)$ and median overall survival (5.65 months versus 4.41 months, $P=0.0025)$ when compared with 5-fluorouracil as first-line treatment for patients with locally advanced or metastatic disease. The probability of surviving beyond one year in this trial was $18 \%$ for patients treated with gemcitabine and $2 \%$ for patients treated with 5 -fluorouracil. ${ }^{8}$

Following the results of this study, single-agent gemcitabine represented the mainstay of treatment for advanced pancreatic cancer for many years. However, over the last decade, several studies have shown that adding a second cytotoxic agent to a gemcitabine-based chemotherapy may potentially increase the efficacy of treatment and improve the overall outcome of pancreatic cancer (Table 1).

In a randomized Phase III trial with 313 patients, the combination of gemcitabine plus oxaliplatin was demonstrated to be superior to gemcitabine alone in terms of response rate $(26.8 \%$ versus $17.3 \%, P=0.04)$, progressionfree survival (5.8 months versus 3.7 months, hazard ratio [HR] $0.75, P=0.04)$ and clinical benefit $(38.2 \%$ versus $26.9 \%, P=0.03) .{ }^{57}$ However, the difference in overall survival (primary endpoint of the study) between the treatment groups did not reach statistical significance ( 8.8 months versus 6.9 months, HR 0.82, $P=0.13$ ). Interestingly, no difference 
Table I Main Phase III studies comparing combination chemotherapy versus single-agent gemcitabine in advanced pancreatic cancer

\begin{tabular}{|c|c|c|c|c|c|c|c|c|}
\hline Reference & $\mathbf{n}$ & $\begin{array}{l}\text { Patient } \\
\text { population }\end{array}$ & $\begin{array}{l}\text { Treatment } \\
\text { arms }\end{array}$ & $\begin{array}{l}\text { Primary } \\
\text { endpoint }\end{array}$ & $\begin{array}{l}\text { Response } \\
\text { rate (\%) }\end{array}$ & $\begin{array}{l}\text { Disease } \\
\text { control (\%) }\end{array}$ & $\begin{array}{l}\text { Median PFS } \\
\text { (months) }\end{array}$ & $\begin{array}{l}\text { Median OS } \\
\text { (months) }\end{array}$ \\
\hline $\begin{array}{l}\text { Louvet } \\
\text { et al }{ }^{57}\end{array}$ & 313 & $\begin{array}{l}\text { Locally advanced } \\
\text { or metastatic }\end{array}$ & $\begin{array}{l}\text { Gemcitabine } \\
\text { Gemcitabine- } \\
\text { oxaliplatin }\end{array}$ & OS & $\begin{array}{l}17.3 \\
26.8 \\
(P=0.04)\end{array}$ & $\begin{array}{l}26.9 \\
38.2 \\
(P=0.03)\end{array}$ & $\begin{array}{l}3.7 \\
5.8 \\
\text { HR } 0.75(P=0.04)\end{array}$ & $\begin{array}{l}6.9 \\
8.8 \\
\text { HR } 0.82(P=0.13)\end{array}$ \\
\hline $\begin{array}{l}\text { Heinemann } \\
\text { et } \mathrm{al}^{58}\end{array}$ & 195 & $\begin{array}{l}\text { Locally advanced } \\
\text { or metastatic }\end{array}$ & $\begin{array}{l}\text { Gemcitabine } \\
\text { Gemcitabine- } \\
\text { cisplatin }\end{array}$ & OS & $\begin{array}{l}8.2 \\
10.2 \\
\text { NS }\end{array}$ & $\begin{array}{l}48.5 \\
70.4 \\
(P<0.00 I)\end{array}$ & $\begin{array}{l}3.1 \\
5.3 \\
\text { HR } 0.75(P=0.053)\end{array}$ & $\begin{array}{l}6.0 \\
7.5 \\
\text { HR } 0.80(P=0.15)\end{array}$ \\
\hline $\begin{array}{l}\text { Moore } \\
\text { et } \mathrm{al}^{13}\end{array}$ & 569 & $\begin{array}{l}\text { Locally advanced } \\
\text { or metastatic }\end{array}$ & $\begin{array}{l}\text { Gemcitabine } \\
\text { Gemcitabine- } \\
\text { erlotinib }\end{array}$ & OS & $\begin{array}{l}8.0 \\
8.6 \\
\text { NS }\end{array}$ & $\begin{array}{l}49.2 \\
57.5 \\
(P=0.07)\end{array}$ & $\begin{array}{l}3.7 \\
3.5 \\
\text { HR } 0.77(P=0.004)\end{array}$ & $\begin{array}{l}5.9 \\
6.2 \\
\text { HR } 0.82(P=0.038)\end{array}$ \\
\hline $\begin{array}{l}\text { Poplin } \\
\text { et al }{ }^{14}\end{array}$ & 547 & $\begin{array}{l}\text { Locally advanced } \\
\text { or metastatic }\end{array}$ & $\begin{array}{l}\text { Gemcitabine } \\
\text { Gemcitabine- } \\
\text { oxaliplatin }\end{array}$ & OS & $\begin{array}{l}6.0 \\
9.0 \\
\text { NS }\end{array}$ & NA & $\begin{array}{l}2.6 \\
2.7 \\
(P=0.10)\end{array}$ & $\begin{array}{l}4.9 \\
5.7 \\
\text { HR } 0.88(P=0.22)\end{array}$ \\
\hline $\begin{array}{l}\text { Cunningham } \\
\text { et al }{ }^{10}\end{array}$ & 533 & $\begin{array}{l}\text { Locally advanced } \\
\text { or metastatic }\end{array}$ & $\begin{array}{l}\text { Gemcitabine } \\
\text { Gemcitabine- } \\
\text { capecitabine }\end{array}$ & OS & $\begin{array}{l}12.4 \\
19.1 \\
(P=0.034)\end{array}$ & $\begin{array}{l}41.7 \\
48.7 \\
\text { NA }\end{array}$ & $\begin{array}{l}3.8 \\
5.3 \\
\text { HR } 0.78(P=0.004)\end{array}$ & $\begin{array}{l}6.2 \\
7.1 \\
\text { HR } 0.86(P=0.08)\end{array}$ \\
\hline $\begin{array}{l}\text { Colucci } \\
\text { et al }{ }^{59}\end{array}$ & 400 & $\begin{array}{l}\text { Locally advanced } \\
\text { or metastatic }\end{array}$ & $\begin{array}{l}\text { Gemcitabine } \\
\text { Gemcitabine- } \\
\text { cisplatin }\end{array}$ & OS & $\begin{array}{l}10.1 \\
12.9 \\
(P=0.37)\end{array}$ & NA & $\begin{array}{l}3.9 \\
3.8 \\
\text { HR } 0.97(P=0.80)\end{array}$ & $\begin{array}{l}8.3 \\
7.2 \\
\text { HR I.IO }(P=0.38)\end{array}$ \\
\hline $\begin{array}{l}\text { Conroy } \\
\text { et a }\left.\right|^{15}\end{array}$ & 342 & Metastatic & $\begin{array}{l}\text { Gemcitabine } \\
\text { FOLFIRINOX }\end{array}$ & OS & $\begin{array}{l}9.4 \\
31.6 \\
(P<0.001)\end{array}$ & $\begin{array}{l}50.9 \\
70.2 \\
(P<0.001)\end{array}$ & $\begin{array}{l}3.3 \\
6.4 \\
\text { HR } 0.47(P<0.00 I)\end{array}$ & $\begin{array}{l}6.8 \\
\text { II.I } \\
\text { HR } 0.57(P<0.00 \text { I })\end{array}$ \\
\hline $\begin{array}{l}\text { Von Hoff } \\
\text { et al }{ }^{16}\end{array}$ & 861 & Metastatic & $\begin{array}{l}\text { Gemcitabine } \\
\text { Gemcitabine- } \\
\text { nab-paclitaxel }\end{array}$ & OS & $\begin{array}{l}7.0 \\
23.0 \\
(P<0.00 I)\end{array}$ & $\begin{array}{l}33.0 \\
48.0 \\
(P<0.001)\end{array}$ & $\begin{array}{l}3.7 \\
5.5 \\
\text { HR } 0.69(P<0.001)\end{array}$ & $\begin{array}{l}6.7 \\
8.5 \\
\text { HR } 0.72(P<0.00 I)\end{array}$ \\
\hline
\end{tabular}

Abbreviations: FOLFIRINOX, 5-fluorouracil, folinic acid, irinotecan and oxaliplatin; HR, hazards ratio; NA, not available; OS, overall survival; PFS, progression-free survival.

in any outcome measure was reported for the combination of gemcitabine plus oxaliplatin versus gemcitabine alone in a subsequent Phase III trial $(\mathrm{n}=447)$ in which fixed-dose rate gemcitabine was also assessed. ${ }^{14}$ In both studies, an increased risk of grade $\geq 3$ toxicity (in particular myelosuppression, vomiting, and peripheral neuropathy) was observed in the combination arm.

Similarly, in a randomized Phase III trial of gemcitabine plus cisplatin versus gemcitabine alone $(n=195)$, use of a combination treatment was associated with prolonged progression-free survival (5.3 months versus 3.1 months, HR 0.75, $P=0.053$ ); however, the advantage in overall survival (primary endpoint of the study) for the gemcitabinecisplatin group (7.5 months versus 6.0 months) was not statistically significant (HR $0.80, P=0.15$ ). In this trial, an increased trend towards a statistically significant benefit for the combination arm $(P=0.051)$ was observed in the subgroup of patients with better performance status (Karnofsky performance status $90 \%-100 \%) .{ }^{58}$ In contrast, in a larger similarly designed study $(\mathrm{n}=400)$, a different schedule of gemcitabine-cisplatin was not demonstrated to provide any clinical advantage in response rate or survival outcomes over gemcitabine alone..$^{59}$
A subsequent pooled analysis of two Phase III trials showed that combination of gemcitabine with a platinum analog significantly improved progression-free survival (HR $0.75, P=0.003$ ) and overall survival (HR $0.81, P=0.031$ ) as compared with single-agent gemcitabine. ${ }^{60}$ Moreover, an increased benefit from the doublet chemotherapy was found in patients with good performance status (HR 0.64 and HR 0.72 for progression-free survival and overall survival, respectively).

Similar results to those reported for adding a platinum compound to gemcitabine were observed with the combination of gemcitabine plus capecitabine. In a large randomized Phase III trial $(n=533)$ in the UK, addition of capecitabine to single-agent gemcitabine significantly improved the objective response rate $(19.1 \%$ versus $12.4 \%, P=0.034)$ and progression-free survival (5.3 months versus 3.8 months, HR $0.78, P=0.004$ ) and did not compromise patient quality of life. ${ }^{10}$ In analysis of the primary endpoint of overall survival, only a trend towards an advantage for the combination arm was observed (7.1 months versus 6.2 months, HR $0.86, P=0.08)$. However, after pooling this trial with two randomized trials of gemcitabine versus gemcitabine plus capecitabine ( $\mathrm{n}=935),{ }^{9,61}$ a significant improvement in overall 
survival was found in favor of the combination treatment (HR, 0.86, $P=0.02){ }^{10}$

Further support for the use of combination chemotherapy was provided by the results of several meta-analyses of randomized studies comparing single-agent gemcitabine versus gemcitabine-based doublet chemotherapy. In a large meta-analysis of 19 studies with no interstudy heterogeneity, gemcitabine-based combinations significantly improved overall survival compared with single-agent gemcitabine (HR 0.91, 95\% confidence interval [CI] 0.85-0.97). ${ }^{62}$ Interestingly, these results seemed to be largely driven by the comparison analysis of gemcitabine alone versus gemcitabine combined with either a platinum agent (HR 0.85, 95\% CI 0.74-0.96) or capecitabine (HR $0.83,95 \%$ CI $0.72-0.96$ ). Indeed, in a subgroup analysis, there was insufficient evidence to suggest a survival advantage for the combination of gemcitabine with either 5-fluorouracil (HR 0.98, 95\% CI 0.86-1.11) or irinotecan (HR 1.01, 95\% CI 0.84-1.22). These results were confirmed in another meta-analysis where a subgroup analysis of 1,682 patients with adequate information on baseline performance status also showed that combination chemotherapy was associated with a significant survival benefit in patients with good performance status (Eastern Cooperative Oncology Group 0-1 or Karnofsky performance status 90\%-100\%; HR $0.76,95 \%$ CI $0.67-0.87, P<0.0001) .{ }^{63}$ In contrast, use of combination chemotherapy did not appear to improve the outcome for patients with a baseline poor performance status (HR1.08, 95\% CI 0.90-1.29, $P=0.40$ ).

Although associated with a clinically marginal improvement in outcome, erlotinib is the only targeted agent that has been granted US Food and Drug Administration approval for first-line treatment of advanced pancreatic cancer in combination with gemcitabine. In a randomized Phase III trial $(n=569)$, the combination treatment with this antiepidermal growth factor receptor agent was demonstrated to be associated with a statistically significant improvement in overall survival over gemcitabine alone (6.24 months versus 5.91 months, HR 0.82, $P=0.038) .{ }^{13}$ The one-year survival rates were $23 \%$ for the gemcitabine-erlotinib arm and $17 \%$ for the gemcitabine alone arm $(P=0.023)$. Combination therapy was also associated with an increase in median progression-free survival (3.75 months versus 3.55 months, HR $0.77 ; P=0.004)$. No difference between the two treatment arms was observed in terms of objective response rate $(8.6 \%$ versus $8.0 \%$ ).

More recently, evidence has emerged that a more intensive treatment regimen including a combination of three cytotoxic drugs is feasible and effective in patients with metastatic disease and a good performance status. In a randomized Phase III trial ( $n=342$, Eastern Cooperative Oncology Group performance status $0-1$ ), the combination of oxaliplatin, irinotecan, and fluorouracil with leucovorin (FOLFIRINOX) was demonstrated to be superior to gemcitabine alone in terms of response rate $(31.6 \%$ versus $9.4 \%, P<0.001)$, progression-free survival (6.4 months versus 3.3 months, HR 0.47, $P<0.001$ ), and overall survival (11.1 months versus 6.8 months, HR $0.57, P<0.001) .{ }^{15}$ The investigational arm was associated with an increased risk of grade $\geq 3$ adverse events, especially neutropenia, febrile neutropenia, thrombocytopenia, diarrhea, and sensory neuropathy. However, it is worth noting that the analysis of quality of life showed that, at 6 months, $66 \%$ of patients in the gemcitabine alone arm experienced a deterioration of quality of life compared with $31 \%$ of patients in the FOLFIRINOX arm (HR 0.47 , $P<0.001)$. Moreover, the time to deterioration in quality of life was reported to be delayed in the investigational arm when compared with the control arm for all functional and symptom scales and with respect to appetite loss, dyspnea, and constipation.

\section{New formulation of taxanes and nab-paclitaxel in advanced pancreatic cancer}

Taxanes have been widely tested in pancreatic cancer, either in monotherapy or as combination therapy with gemcitabine or other chemotherapy agents. ${ }^{64}$ Both paclitaxel and docetaxel were associated with modest activity (response rate $0 \%-15 \%$, median time to progression 1-5 months, overall survival 5-8.5 months) when given as single agents in previously untreated patients. ${ }^{65-68}$ Single-arm or randomized Phase II trials including combination of a taxane plus gemcitabine showed interesting results (response rate up to $40 \%$ and median overall survival up to 9 months), possibly confirming the preclinical data suggesting a synergistic effect of this combination. ${ }^{69-72}$ However, given the design of these studies, the small numbers, and the potential biases associated with patient selection, these results are difficult to interpret.

Recently, new paclitaxel formulations have been investigated in pancreatic cancer with the aim to overcome abundant fibrous desmoplasia and increase drug delivery to the tumor cells. In a single-arm study of 56 patients, monotherapy with paclitaxel-loaded polymeric micelles has been reported to achieve disease control in $60 \%$ of cases, with a progression-free survival of 2.8 months and an overall survival of 6.5 months. ${ }^{73}$ In a four-arm, randomized Phase II trial $(n=212)$, different dosages of EndoTAG ${ }^{\circledR}-1$ (Medigene AG, 
Planegg/Martinsried, Germany), a novel formulation of charged liposomes carrying paclitaxel embedded in the cationic liposome membrane and selectively delivering the drug to the intratumoral endothelial cells, were investigated in association with gemcitabine versus gemcitabine alone. ${ }^{74}$ Although the response rate was comparable across the four treatment groups $(14 \%-16 \%)$, the median progression-free survival and overall survival were longer in the combination arms (from 4.1 to 4.6 months and from 8.1 to 9.3 months, respectively) compared with the gemcitabine alone group (2.7 months and 6.8 months, respectively). The toxicity profile of the gemcitabine plus EndoTAG ${ }^{\circledR}-1$ combination was favorable and, interestingly, no treatment-related neuropathy was reported in the trial. These results support the hypothesis that use of new formulations of taxanes may improve the efficacy of these agents and also improve their safety profile and minimize the risk of toxicity, especially when given in association with other cytotoxic drugs.

Nab-paclitaxel (Abraxane ${ }^{\circledR}$; Celgene, Summit, NJ, USA) is a $130 \mathrm{~nm}$ albumin-bound formulation of paclitaxel particles initially developed to reduce the toxicity associated with the oil-based solvents required to solubilize paclitaxel. ${ }^{75}$ Moreover, this novel formulation is associated with increased delivery of the drug into tumor tissue, possibly mediated by active transport of albumin into the interstitial space via gp60mediated transcytosis or binding of albumin to SPARC. ${ }^{76,77}$ In preclinical studies conducted in murine models of pancreatic cancer, nab-paclitaxel showed antitumor activity as a single agent and synergistic activity in combination with gemcitabine. ${ }^{78}$ Interestingly, nab-paclitaxel was demonstrated to increase the intratumoral concentration of gemcitabine by decreasing protein levels of the primary gemcitabinemetabolizing enzyme, cytidine deaminase. ${ }^{79}$

In a Phase I/II trial in patients with previously untreated metastatic pancreatic cancer $(n=67)$, administering nabpaclitaxel in combination with standard-dose gemcitabine was demonstrated to be safe at the maximum tolerated dose of $125 \mathrm{mg} / \mathrm{m}^{2} .^{78}$ The dose-limiting toxicities were sepsis and neutropenia, and the most common treatment-related adverse events that led to treatment discontinuation were neuropathy and fatigue. Interestingly, use of this combination was associated with significant activity and promising survival outcomes. Indeed, in the group of patients treated at the maximum tolerated dose of nab-paclitaxel $(n=44)$, the response rate was $48 \%$ and the overall disease control rate was $68 \%$. Moreover, in the same group, median progression-free survival and overall survival were 7.9 months and 12.2 months, respectively, and the one-year survival rate was $48 \%$.
These results were confirmed in a recent international, multicenter, open-label, randomized Phase III trial conducted in 861 patients with untreated metastatic pancreatic cancer. ${ }^{16}$ In this trial, patients with a Karnofsky performance status $\geq 70$ were randomized in a $1: 1$ ratio to receive nabpaclitaxel plus gemcitabine versus gemcitabine alone. Of note, the trial excluded patients who had previously received adjuvant systemic chemotherapy and did not allow crossover at the time of progressive disease. The primary endpoint of the study was overall survival. The analysis conducted in the intention-to-treat population showed a statistically significant advantage in favor of the combination treatment, with a median overall survival of 8.5 months for the experimental arm compared with 6.7 months for the control arm (HR 0.72, $P<0.0001$ ). The 1-year and 2-year survival rates were $35 \%$ and $9 \%$ for gemcitabine-nab-paclitaxel and $22 \%$ and $4 \%$ for gemcitabine alone, respectively. Of note, use of subsequent treatments was similar in the treatment groups and the survival advantage for the combination arm was confirmed even when data for survival were censored at the time of the initiation of second-line therapy. Similarly, addition of nab-paclitaxel was associated with longer progression-free survival (5.5 months versus 3.7 months, HR 0.69, $P<0.0001$ ), increased tumor response rate (23\% versus $7 \%$ ), and a higher rate of disease control (48\% versus 33\%) compared with single-agent gemcitabine.

Treatment was generally well tolerated, with patients in the investigational arm receiving $81 \%$ and $75 \%$ of the protocol-specified nab-paclitaxel and gemcitabine doses, respectively. There was no difference between the two treatment groups in term of incidence of serious adverse events (50\% with nab-paclitaxel plus gemcitabine and $43 \%$ with gemcitabine) or fatal events (4\% in each treatment group). Neutropenia (38\% versus 27\%), leukopenia ( $31 \%$ versus $16 \%$ ), fatigue (17\% versus $7 \%$ ), and peripheral neuropathy ( $17 \%$ versus $1 \%$ ) were the treatment-related grade $\geq 3$ adverse events, which were reported to occur more frequently in the combination group than in the control group. Of note, peripheral neuropathy was cumulative but rapidly reversible after discontinuation of treatment.

Based on these data, nab-paclitaxel has recently obtained approval from both the US Food and Drug Administration and European Medicines Agency for use in combination with gemcitabine for the first-line treatment of patients with metastatic pancreatic cancer. Moreover, given the promising activity and manageable toxicity observed in this trial, the combination of gemcitabine plus nab-paclitaxel is currently being tested in different treatment settings in association with 
other cytotoxic drugs or novel agents targeting the pancreatic stroma (Table 2). Other treatment schedules of gemcitabine and nab-paclitaxel (ie, biweekly dosing) are being assessed to see whether the safety profile of this combination can be improved (NCT01851174). ${ }^{80}$

The efficacy of nab-paclitaxel has also been assessed in previously treated metastatic pancreatic cancer patients. In a small Phase II trial of nab-paclitaxel monotherapy in patients who progressed on gemcitabine-based therapy $(n=19)$, one patient had a confirmed partial response and six $(32 \%)$ had stable disease as their best response. Eleven $(58 \%)$ patients were alive at 6 months (primary endpoint of the study), and estimated median progression-free survival and overall survival were 1.7 months and 7.3 months, respectively. ${ }^{81}$ Treatment was overall well tolerated, with grade $\geq 3$ neutropenia, febrile neutropenia, and anemia occurring in $32 \%, 11 \%$, and $11 \%$ of patients, respectively.

\section{Nab-paclitaxel in locally advanced pancreatic cancer}

The activity of nab-paclitaxel observed in association with gemcitabine in patients with metastatic disease has prompted investigation of this combination therapy in other treatment settings. Most of the currently available data are from small Phase II trials in which gemcitabine-nabpaclitaxel was given as a preoperative treatment in patient with resectable or potentially resectable locally advanced pancreatic cancer.
In a recent pilot, multicenter Phase II trial in patients with resectable disease $(n=25)$, administering three cycles of neoadjuvant gemcitabine-nab-paclitaxel was feasible and associated with radiological and biochemical response (16\% and $60 \%$, respectively). ${ }^{82}$ Twenty of 25 patients $(80 \%)$ underwent surgical resection, and in 19 cases this was a radical (R0) resection. The primary endpoint of the study was a $>90 \%$ postoperative histological tumor response (grade 3/4), and this was reported in six patients (30\%).

Similar results were reported in a small cohort of patients with resectable or borderline resectable pancreatic cancer $(n=16) .{ }^{83}$ More interestingly, in this study, the clinical and pathological effects of two cycles of neoadjuvant gemcitabine-nab-paclitaxel were also investigated by elastography, an endoscopic ultrasound-based technique for noninvasive assessment of the tumor stroma. The authors reported that the elastography ratio value diminished significantly after treatment and correlated with improvement in the maximum standardized uptake value and carbohydrate antigen (CA19.9) response, emerging as an attractive method to monitor tumor response. Analysis of residual tumors of patients treated with nab-paclitaxel plus gemcitabine revealed a less abundant peritumoral fibrillar collagen matrix and a smaller number of cancer-associated fibroblasts compared with a control group of untreated or conventionally treated patients. Moreover, in areas of tumor regression, collagen had an amorphous structure, with a discontinuous and disorganized network of type I collagen fibers.

Table 2 Ongoing clinical trials investigating the addition of an anti-stroma agent to the combination of gemcitabine and nab-paclitaxel in pancreatic cancer

\begin{tabular}{|c|c|c|c|c|}
\hline Trial ID & Agent & Mechanism of action & Patient population & Study design \\
\hline NCT020053I5106 & Vantictumab (OMPI8R5) & $\begin{array}{l}\text { Human mAb targeting the } \\
\text { WNT pathway }\end{array}$ & Ist line, metastatic & $\begin{array}{l}\text { Phase Ib dose escalation } \\
\text { study }\end{array}$ \\
\hline NCT0I43I794107 & Erismodegib (LDE225) & Oral hedgehog inhibitor & Borderline resectable & $\begin{array}{l}\text { Open-label Phase I/2 } \\
\text { randomized study }\end{array}$ \\
\hline NCT0I0888I $5^{108}$ & Vismodegib (GDC-0449) & Oral hedgehog inhibitor & Ist line, metastatic & Single arm Phase 2 study \\
\hline NCT0I839487 109 & PEGPH20 & $\begin{array}{l}\text { PEGylated recombinant } \\
\text { human hyaluronidase }\end{array}$ & Ist line, metastatic & $\begin{array}{l}\text { Open-label Phase } 2 \\
\text { randomized study }\end{array}$ \\
\hline NCT0I804530110 & PLX7486-TsOH & TKI inhibitor tosylate salt & $\begin{array}{l}\text { Advanced non- } \\
\text { resectable (part 2) }\end{array}$ & $\begin{array}{l}\text { Phase I dose-escalation } \\
\text { study }\end{array}$ \\
\hline NCT0I647828"II & OMP-59R5 & Anti-notch receptor $\mathrm{mAb}$ & Ist line, metastatic & $\begin{array}{l}\text { Open-label Phase I/2 } \\
\text { randomized study }\end{array}$ \\
\hline NCT0I46I915112 & ODSH & $\begin{array}{l}\text { Low anticoagulant heparin } \\
\text { derivate }\end{array}$ & Ist line, metastatic & $\begin{array}{l}\text { Open-label Phase } 2 \\
\text { randomized study }\end{array}$ \\
\hline NCT0I62/243/13 & M402 & Heparan sulfate mimetic & $\begin{array}{l}\text { Metastatic pancreatic } \\
\text { cancer }\end{array}$ & $\begin{array}{l}\text { Double-blinded Phase I/2 } \\
\text { randomized study }\end{array}$ \\
\hline NCT0I8448I7 $7^{1 / 4}$ & Apatorsen (OGX-427) & $\begin{array}{l}\text { Antisense oligonucleotide } \\
\text { targeting HSP } 27\end{array}$ & Ist line, metastatic & $\begin{array}{l}\text { Double-blinded Phase } 2 \\
\text { randomized study }\end{array}$ \\
\hline NCT0I858883!15 & INCB039II0 & $\begin{array}{l}\text { Selective Janus Kinase-I } \\
\text { inhibitor }\end{array}$ & Advanced or metastatic & Phase Ib study \\
\hline
\end{tabular}

Abbreviations: mAb, monoclonal antibody; TKI, tyrosine kinase inhibitor; HSP, heat shock protein; PEGPH20, (PEGylated Recombinant Human Hyaluronidase); ODSH, (2-0, 3-0 Desulfated Heparin). 
The preliminary results of a pilot study assessing a sequential neoadjuvant strategy with two cycles of gemcitabine-nab-paclitaxel followed by two cycles of FOLFIRINOX in patients with locally advanced, stage III pancreatic cancer have been recently reported. ${ }^{84}$ The first eight study patients completed the planned four cycles of treatment, and sequential therapy was feasible in that there were no unexpected toxicities, and administering gemcitabine-nab-paclitaxel did not appear to adversely affect the safety profile of FOLFIRINOX. Five partial responses (63\%) and three cases of stable disease (37\%) were observed, and three patients (37\%) underwent an $\mathrm{R} 0$ resection. The authors reported tumor regression in all resected patients, with one pathological complete response.

Additional clinical trials are currently further investigating the clinical potential of nab-paclitaxel in other treatment settings, including a large, multicenter, randomized, Phase III study of gemcitabine-nab-paclitaxel versus gemcitabine alone as adjuvant treatment following R0 or R1 resection (Table 3). The results of these trials will certainly provide more information on the role of this novel agent within the therapeutic landscape of pancreatic cancer. In particular, it will be very interesting to see whether the antitumor effects of nab-paclitaxel observed in the presence of macroscopic disease are maintained in the setting of microscopic disease where the clinical relevance of the peritumoral stroma and the characteristics of the tumor microenvironment may be markedly different.

\section{SPARC and nab-paclitaxel}

SPARC, also known as osteonectin or BM-40, is an albuminbinding $42 \mathrm{kDa}$ multifunctional glycoprotein highly expressed during mammalian development and tissue differentiation, and usually declines after organ maturation. ${ }^{81}$ SPARC expression has been suggested to have a role in tissue remodeling during several physiological or pathological processes, including wound healing, angiogenesis, and tumorigenesis. ${ }^{85}$

In pancreatic cancer, SPARC is expressed in the tumor microenvironment in approximately $80 \%$ of cases. ${ }^{86,87}$ Cytoplasmic staining for this glycoprotein is strongest in fibroblastic cells immediately adjacent to infiltrating cancer cells and significantly less common in pancreatic cancer cells. ${ }^{77}$ Expression of SPARC in pancreatic cancer has been reported to correlate with poor outcome. ${ }^{77,88}$ However, the biological rationale for this correlation and the mechanisms whereby expression of this glycoprotein may influence the outcome of pancreatic cancer are largely unknown. ${ }^{89}$ Expression of SPARC by stromal fibroblasts may be a generic indicator of an activated fibroblast phenotype or may influence pericyte migration, collagen deposition, and ultimately facilitate development of dense collagenous stroma. ${ }^{89-91}$

More recently, SPARC has emerged as a potential biomarker in pancreatic cancer. Nab-paclitaxel was previously shown to have antitumor activity in various types of cancer that overexpress SPARC..$^{92-100}$ In a Phase I/II study of gemcitabine plus nab-paclitaxel in pancreatic cancer, increased expression of SPARC in stromal cells, but not in cancer cells, was found to be associated with improved overall survival. ${ }^{78}$ Although only 36 study patients were assessable for SPARC; the median overall survival for patients with high-SPARC tumors was 17.8 months versus 8.1 months in the group of patients with low-SPARC tumors $(P=0.043)$. This finding is in contrast with historical reports on the association between SPARC expression and poor outcome, and suggested that stromal SPARC may represent a useful marker of activity for gemcitabine plus nab-paclitaxel combination regimens in pancreatic cancer. However, it is worth noting

Table 3 Main clinical trials with gemcitabine and nab-paclitaxel in other treatment settings of pancreatic cancer

\begin{tabular}{|c|c|c|c|c|c|}
\hline Trial ID & Indication & Patient population & Treatment arms & Study design & Primary endpoint \\
\hline NCT0I964430116 & Adjuvant & $\begin{array}{l}\text { Resected (R0 or RI) } \\
\text { Stage T I-3, N 0-I, M0 }\end{array}$ & $\begin{array}{l}\text { Gemcitabine vs Gemcitabine } \\
\text { nab-paclitaxel }\end{array}$ & $\begin{array}{l}\text { Open-label, } \\
\text { randomized Phase } 3\end{array}$ & Disease-free survival \\
\hline NCT0।978I84!17 & Neoadjuvant & $\begin{array}{l}\text { Potentially or } \\
\text { borderline respectable }\end{array}$ & $\begin{array}{l}\text { Gemcitabine nab-paclitaxel vs } \\
\text { Gemcitabine nab-paclitaxel plus } \\
\text { hydroxychloroquine }\end{array}$ & $\begin{array}{l}\text { Open-label Phase } 2 \\
\text { randomized study }\end{array}$ & Histologic response \\
\hline NCT0।4704I $7^{118}$ & Neoadjuvant & $\begin{array}{l}\text { Resectable and } \\
\text { borderline respectable }\end{array}$ & $\begin{array}{l}\text { Low-risk resectable: Gemcitabine } \\
\text { nab-paclitaxel followed by surgery } \\
\text { High-risk/borderline resectable: } \\
\text { Gemcitabine nab-paclitaxel } \\
\text { followed by CRT and surgery }\end{array}$ & $\begin{array}{l}\text { Non-randomized } \\
\text { Phase } 2 \text { study }\end{array}$ & $\begin{array}{l}\text { Biochemical response } \\
\text { Radiologic response } \\
\text { Pathologic downstaging } \\
\text { R0 resection rate }\end{array}$ \\
\hline NCT02024009"19 & $\begin{array}{l}\text { Locally advanced } \\
\text { disease }\end{array}$ & $\begin{array}{l}\text { Unresectable, locally } \\
\text { advanced }\end{array}$ & $\begin{array}{l}\text { Gemcitabine nab-paclitaxel } \\
\text { followed by CRT ( } 50.4 \text { or } 60 \mathrm{~Gy} \text { ) } \\
\text { with or without Nelfinavir }\end{array}$ & $\begin{array}{l}\text { Randomized Phase 2/3 } \\
\text { study }\end{array}$ & Overall survival \\
\hline
\end{tabular}

Abbreviation: CRT, chemoradiotherapy. 
that data from preclinical and clinical studies investigating the role of SPARC as a potential predictive biomarker for the benefit of nab-paclitaxel in pancreatic cancer and other types of tumors have been inconsistent. ${ }^{101-104}$

In a recent pharmacokinetic and pharmacodynamic analysis of cremophor-paclitaxel, nab-paclitaxel and a novel mouse albumin nab-paclitaxel in a genetically engineered mouse model of pancreatic cancer, Neesse et al found that circulating SPARC levels, but not stromal-derived SPARC, may influence the intravascular concentration and tissue delivery of low-dose nab-paclitaxel. However, accumulation and activity of nab-paclitaxel were largely dose-dependent and not affected by SPARC when nab-paclitaxel was administered at therapeutic doses. ${ }^{105}$ The prognostic or predictive role of SPARC expression in tumor specimens from MPACT (the Metastatic Pancreatic Adenocarcinoma Clinical Trial) ${ }^{16}$ is currently being investigated, and the results of these analyses are eagerly awaited.

\section{Conclusion}

After several years during which no major changes were introduced in the routine management of advanced pancreatic cancer, the treatment paradigm for this disease has recently evolved. Two large randomized Phase III trials ${ }^{15,16}$ have provided definitive evidence that more intensive treatments are feasible in patients with good performance status and are associated with better outcome. As a result, oncologists have now an increased number of treatment options for patients with advanced pancreatic cancer and can tailor therapy according to patient characteristics. Patient performance status, comorbidities, drug-related toxicities, and treatment goals are increasingly being taken into consideration in routine practice to individualize therapeutic strategies and optimize the treatment risk/benefit profile for each patient. Moreover, studies are currently investigating whether the antitumor activity and clinical benefit observed with the new combination regimens in the advanced setting can be replicated in the setting of adjuvant and neoadjuvant treatment.

Nab-paclitaxel is already being used for the treatment of metastatic pancreatic cancer in many countries. Although initially developed for a different purpose, this drug can be considered as the prototype of antitumor agents that couple inherent cytotoxic activity with an ability to overcome the mechanical barrier of the pancreatic peritumoral stroma. Moreover, its acceptable safety profile and synergistic interaction with gemcitabine suggest that the gemcitabinenab-paclitaxel combination is not only an option for first-line treatment of patients with advanced disease but may also represent the optimal chemotherapy backbone for evaluation of combination treatments, including standard chemotherapy agents and promising agents with alternative mechanisms of action. Identification of those patients most likely to benefit from nab-paclitaxel could certainly maximize the efficacy of this agent. Although preliminary data suggest an association between the benefit of nab-paclitaxel and expression of SPARC, further investigation is needed to validate SPARC as a clinically useful predictive biomarker.

It is undeniable that, despite the general enthusiasm associated with the recent advent of new treatment options, the overall prognosis of advanced pancreatic cancer is still poor and several challenges remain in the management of this disease. More studies are certainly needed to elucidate further the biology of pancreatic cancer and promote development of new therapeutic strategies that could overcome the inherent mechanisms of resistance to treatment.

It is now established that the peritumoral stroma plays a key role in the development of pancreatic cancer and has a strong influence on the biological behavior of this disease. Trying to better understand the interactions between tumor cells and the complex network of stromal components and define their exact role in pancreatic carcinogenesis and tumor progression are certainly some of the next and most important challenges. Several promising antistromal agents are currently under investigation, and the results of these studies will determine whether targeting the stroma is a valid therapeutic option in this disease.

\section{Acknowledgments}

We acknowledge support from the National Institute for Health Research Biomedical Research Centre at the Royal Marsden Hospital and Institute of Cancer Research and from the Peter Stebbings Memorial Charity.

\section{Disclosure}

Prof David Cunningham has received research funding from Roche, Amgen, Celgene, Sanofi-Aventis and Merck Serono. The authors report no other conflicts of interest in this work.

\section{References}

1. Ferlay J, Steliarova-Foucher E, Lortet-Tieulent J, et al. Cancer incidence and mortality patterns in Europe: estimates for 40 countries in 2012. Eur J Cancer. 2013;49:1374-1403.

2. Malvezzi M, Bertuccio P, Levi F, La Vecchia C, Negri E. European cancer mortality predictions for the year 2013. Ann Oncol. 2013;24:792-800.

3. Siegel R, Naishadham D, Jemal D. Cancer Statistics, 2013. CA Cancer J Clin. 2013;63:11-30

4. Willett CG, Czito BJ, Bendell JC, Ryan DP. Locally advanced pancreatic cancer. J Clin Oncol. 2005;23:4538-4544.

5. Neoptolemos JP, Stocken DD, Bassi C, et al. Adjuvant chemotherapy with fluorouracil plus folinic acid vs gemcitabine following pancreatic cancer resection: a randomized controlled trial. JAMA. 2010;304:1073-1081. 
6. Oettle H, Neuhaus P, Hochhaus A, et al. Adjuvant chemotherapy with gemcitabine and long-term outcomes among patients with resected pancreatic cancer: the CONKO-001 randomized trial. JAMA. 2013;310: 1473-1481.

7. Tempero MA, Berlin J, Ducreux M, et al. Pancreatic cancer treatment and research: an international expert panel discussion. Ann Oncol. 2011;22:1500-1506.

8. Burris HA 3rd, Moore MJ, Andersen J, et al. Improvements in survival and clinical benefit with gemcitabine as first-line therapy for patients with advanced pancreas cancer: a randomized trial. J Clin Oncol. 1997; 15:2403-2413.

9. Herrmann R, Bodoky G, Ruhstaller T, et al. Gemcitabine plus capecitabine compared with gemcitabine alone in advanced pancreatic cancer: a randomized, multicenter, Phase III trial of the Swiss Group for Clinical Cancer Research and the Central European Cooperative Oncology Group. J Clin Oncol. 2007;25:2212-2217.

10. Cunningham D, Chau I, Stocken DD, et al. Phase III randomized comparison of gemcitabine versus gemcitabine plus capecitabine in patients with advanced pancreatic cancer. J Clin Oncol. 2009;27: 5513-5518.

11. Philip PA, Benedetti J, Corless CL, et al. Phase III study comparing gemcitabine plus cetuximab versus gemcitabine in patients with advanced pancreatic adenocarcinoma: Southwest Oncology Group directed Intergroup Trial S0205. J Clin Oncol. 2010;28:3605-3610.

12. Kindler HL, Niedzwiecki D, Hollis D, et al. Gemcitabine plus bevacizumab compared with gemcitabine plus placebo in patients with advanced pancreatic cancer: Phase III trial of the Cancer and Leukemia Group B (CALGB 80303). J Clin Oncol. 2010;28:3617-3622.

13. Moore MJ, Goldstein D, Hamm J, et al. Erlotinib plus gemcitabine compared with gemcitabine alone in patients with advanced pancreatic cancer: a Phase III trial of the National Cancer Institute of Canada Clinical Trials Group. J Clin Oncol. 2007;25:1960-1966.

14. Poplin E, Feng Y, Rothenberg ML, et al. Phase III trial of gemcitabine and oxaliplatin versus gemcitabine (fixed-dose rate infusion) compared with gemcitabine (30-minute infusion) in patients with pancreatic carcinoma E6201: a trial of the Eastern Cooperative Oncology Group. J Clin Oncol. 2009;27:3778-3785.

15. Conroy T, Desseigne F, Ychou M, et al. FOLFIRINOX versus gemcitabine for metastatic pancreatic cancer. $N$ Engl J Med. 2011;364: $1817-1825$

16. Von Hoff DD, Ervin T, Arena FP, et al. Increased survival in pancreatic cancer with nab-paclitaxel plus gemcitabine. $N$ Engl J Med. 2013;31:369:1691-1703.

17. Heinemann V, Reni M, Ychou M, Richel DJ, Macarulla T, Ducreux M. Tumour-stroma interactions in pancreatic ductal adenocarcinoma: rationale and current evidence for new therapeutic strategies. Cancer Treat Rev. 2014;40:118-128.

18. Erkan M, Hausmann S, Michalski CW, et al. The role of stroma in pancreatic cancer: diagnostic and therapeutic implications. Nat Rev Gastroenterol Hepatol. 2012;9:454-467.

19. Hidalgo M. Pancreatic cancer. N Engl J Med. 2010;362:1605-1617.

20. Kleeff J, Beckhove P, Esposito I, et al. Pancreatic cancer microenvironment. Int J Cancer. 2007;121:699-705.

21. Mahadevan D, Von Hoff DD. Tumor-stroma interactions in pancreatic ductal adenocarcinoma. Mol Cancer Ther. 2007;6:1186-1197.

22. Bachem MG, Schunemann M, Ramadani M, et al. Pancreatic carcinoma cells induce fibrosis by stimulating proliferation and matrix synthesis of stellate cells. Gastroenterology. 2005;128:907-921.

23. Apte MV, Park S, Phillips PA, et al. Desmoplastic reaction in pancreatic cancer: role of pancreatic stellate cells. Pancreas. 2004;29: 179-187.

24. Farrow B, Sugiyama Y, Chen A, Uffort E, Nealon W, Mark Evers B. Inflammatory mechanisms contributing to pancreatic cancer development. Ann Surg. 2004;239:763-769.

25. Zhu Z, Kleeff J, Kayed H, et al. Nerve growth factor and enhancement of proliferation, invasion, and tumorigenicity of pancreatic cancer cells. Mol Carcinog. 2002;35:138-147.
26. Erkan M, Adler G, Apte MV, et al. Current consensus and discussion on pancreatic stellate cell research. Gut. 2012;61:172-178.

27. Erkan M, Reiser-Erkan C, Michalski CW, et al. The impact of the activated stroma on pancreatic ductal adenocarcinoma biology and therapy resistance. Curr Mol Med. 2012;12:288-303.

28. Ohlund D, Franklin O, Lundberg E, Lundin C, Sund M. Type IV collagen stimulates pancreatic cancer cell proliferation, migration, and inhibits apoptosis through an autocrine loop. BMC Cancer. 2013;13:154.

29. Shields MA, Dangi-Garimella S, Krantz SB, Bentrem DJ, Munshi HG. Pancreatic cancer cells respond to type I collagen by inducing snail expression to promote membrane type 1 matrix metalloproteinasedependent collagen invasion. J Biol Chem. 2011;286:10495-10504.

30. Miyamoto H, Murakami T, Tsuchida K, Sugino H, Miyake H, Tashiro S. Tumor-stroma interaction of human pancreatic cancer: acquired resistance to anticancer drugs and proliferation regulation is dependent on extracellular matrix proteins. Pancreas. 2004;28:38-44.

31. Fujita H, Ohuchida K, Mizumoto K, et al. Tumor-stromal interactions with direct cell contacts enhance proliferation of human pancreatic carcinoma cells. Cancer Sci. 2009;100:2309-2317.

32. Erkan M, Reiser-Erkan C, Michalski CW, Kleeff J. Tumor microenvironment and progression of pancreatic cancer. Exp Oncol. 2010;32: 128-131.

33. Schneiderhan W, Diaz F, Fundel M, et al. Pancreatic stellate cells are an important source of MMP-2 in human pancreatic cancer and accelerate tumor progression in a murine xenograft model and CAM assay. $J$ Cell Sci. 2007;120:512-519.

34. Xu Z, Vonlaufen A, Phillips PA, et al. Role of pancreatic stellate cells in pancreatic cancer metastasis. Am J Pathol. 2010;177: 2585-2596

35. Erkan M, Michalski CW, Rieder S, et al. The activated stroma index is a novel and independent prognostic marker in pancreatic ductal adenocarcinoma. Clin Gastroenterol Hepatol. 2008;6:1155-1161.

36. Hidalgo M, Maitra A. The hedgehog pathway and pancreatic cancer. $N$ Engl J Med. 2009;361:2094-2096.

37. Di Marco M, Macchini M, Vecchiarelli S, Sina S, Biasco G. Hedgehog signaling: from the cuirass to the heart of pancreatic cancer. Pancreatology. 2012;12:388-393.

38. Olive KP, Jacobetz MA, Davidson CJ, et al. Inhibition of Hedgehog signaling enhances delivery of chemotherapy in a mouse model of pancreatic cancer. Science. 2009;324:1457-1461.

39. Jimeno A, Feldmann G, Suarez-Gauthier A, et al. A direct pancreatic cancer xenograft model as a platform for cancer stem cell therapeutic development. Mol Cancer Ther. 2009;8:310-314.

40. Khan GN, Griffith K, Greenson J, et al. Cancer stem cells (CSC) and inhibition of hedgehog $(\mathrm{Hh})$ pathway signaling in advanced pancreatic cancer: GDC-0449 in combination with gemcitabine (Gem). Abstract presented at the American Association for Cancer Research's Pancreatic Cancer: Progress and Challenges conference, Lake Tahoe, Nevada, USA, June 18-21, 2012.

41. Richards DA, Stephenson J, Wolpin BM, et al. A Phase Ib trial of IPI-926 a hedgehog pathway inhibitor plus gemcitabine in patients with metastatic pancreatic cancer. J Clin Oncol. 2012;30 Suppl 4:Abstr 213.

42. Infinity Pharmaceuticals. Infinity reports update from Phase 2 study of saridegib plus gemcitabine in patients with metastatic pancreatic cancer. Available from: http://phx.corporate-ir.net/phoenix. zhtml? c=121941\&p=irol-newsArticle \&ID=1653550\&highlight. Accessed January 02, 2014.

43. Virgil D, Catenacci T, Bahary N, et al. Final analysis of a Phase IB/ randomized Phase II study of gemcitabine $(\mathrm{G})$ plus placebo $(\mathrm{P})$ or vismodegib (V), a hedgehog (Hh) pathway inhibitor, in patients (pts) with metastatic pancreatic cancer (PC): a University of Chicago Phase II consortium study. J Clin Oncol. 2013;31 Suppl:Abstr 4012.

44. ClinicalTrials.Gov. Hedgehog Inhibitors for Metastatic Adenocarcinoma of the Pancreas Available from http:/clinicaltrials.gov/ct2/show/ NCT01088815. ClinicalTrials.gov Identifier: NCT01088815. Accessed March 21, 2014 
45. ClinicalTrials.Gov. FOLFIRINOX Plus IPI-926 for Advanced Pancreatic Adenocarcinoma Available from http://clinicaltrials.gov/ ct2/show/NCT01383538. ClinicalTrials.gov Identifier: NCT01383538. Accessed March 21, 2014.

46. ClinicalTrials.Gov. LDE225 With Fluorouracil, Leucovorin, Oxaliplatin, and Irinotecan for Untreated Advanced Pancreatic Cancer Available from http://clinicaltrials.gov/ct2/show/NCT01485744. ClinicalTrials. gov Identifier: NCT01485744. Accessed March 21, 2014.

47. Provenzano PP, Cuevas C, Chang AE, Goel VK, Von Hoff DD, Hingorani SR. Enzymatic targeting of the stroma ablates physical barriers to treatment of pancreatic ductal adenocarcinoma. Cancer Cell. 2012;21:418-429.

48. Borad MJ, Ramanathan RK, Bessudo A, et al. Targeting hyaluronan (HA) in tumor stroma: a Phase I study to evaluate the safety pharmacokinetics (PK) and pharmacodynamics (PD) of pegylated hyaluronidase (PEGPH20) in patients with solid tumors. J Clin Oncol. 2012;30 Suppl: Abstr 2579.

49. ClinicalTrials. Gov. Study of Gemcitabine + PEGPH20 vs Gemcitabine Alone in Stage IV Previously Untreated Pancreatic Cancer. Available from http://clinicaltrials.gov/ct2/show/NCT01453153. ClinicalTrials. gov Identifier: NCT01453153. Accessed March 21, 2014.

50. Erkan M, Reiser-Erkan C, Michalski CW, et al. Cancer-stellate cell interactions perpetuate the hypoxia-fibrosis cycle in pancreatic ductal adenocarcinoma. Neoplasia. 2009;11:497-508.

51. Masamune A, Kikuta K, Watanabe T, Satoh K, Hirota M, Shimosegawa T. Hypoxia stimulates pancreatic stellate cells to induce fibrosis and angiogenesis in pancreatic cancer. Am J Physiol Gastrointest Liver Physiol. 2008;295:G709-G717.

52. Hwang RF, Yokoi K, Bucana CD, et al. Inhibition of platelet-derived growth factor receptor phosphorylation by STI571 (Gleevec) reduces growth and metastasis of human pancreatic carcinoma in an orthotopic nude mouse model. Clin Cancer Res. 2003;9:6534-6544.

53. Lang SA, Taeger J, Hackl C, et al. Effects of TKI258, a novel FGFR/ PDGFR/VEGFR inhibitor, on pancreatic cancer cells, endothelial cells and pericytes. Abstract 145 presented at the Gastrointestinal Cancers Symposium, San Francisco, CA, USA, January 15-17, 2009.

54. ClinciaTrials. Gov. Dovitinib Lactate, Gemcitabine Hydrochloride, and Capecitabine in Treating Patients With Advanced or Metastatic Solid Tumors, Pancreatic Cancer and Biliary Cancers. Available from http:// clinicaltrials.gov/ct2/show/NCT01497392. ClinicalTrials.gov Identifier: NCT01497392. Accessed March 21, 2014.

55. Palmer KR, Kerr M, Knowles G, et al. Chemotherapy prolongs survival in inoperable pancreatic carcinoma. Br J Surg. 1994;81: $882-885$.

56. Glimelius B, Hoffman K, Sjoden PO, et al. Chemotherapy improves survival and quality of life in advanced pancreatic and biliary cancer. Ann Oncol. 1996;7:593-600.

57. Louvet C, Labianca R, Hammel P, et al. Gemcitabine in combination with oxaliplatin compared with gemcitabine alone in locally advanced or metastatic pancreatic cancer: results of a GERCOR and GISCAD Phase III trial. J Clin Oncol. 2005;23:3509-3516.

58. Heinemann V, Quietzsch D, Gieseler F, et al. Randomized Phase III trial of gemcitabine plus cisplatin compared with gemcitabine alone in advanced pancreatic cancer. J Clin Oncol. 2006;24:3946-3952.

59. Colucci G, Labianca R, Di Costanzo F, et al. Randomized Phase III trial of gemcitabine plus cisplatin compared with single-agent gemcitabine as first-line treatment of patients with advanced pancreatic cancer: the GIP-1 study. J Clin Oncol. 2010;28:1645-1651.

60. Heinemann V, Labianca R, Hinke A, Louvet C. Increased survival using platinum analogue combined with gemcitabine as compared to singleagent gemcitabine in advanced pancreatic cancer: pooled analysis of two randomized trials, the GERCOR/GISCAD Intergroup study and a German multicenter study. Ann Oncol. 2007;18:1652-1659.

61. Scheithauer W, Schull B, Ulrich-Pur H, et al. Biweekly high-dose gemcitabine alone or in combination with capecitabine in patients with metastatic pancreatic adenocarcinoma: a randomized Phase II trial. Ann Oncol. 2003;14:97-104.
62. Sultana A, Smith CT, Cunningham D, Starling N, Neoptolemos JP, Ghaneh P. Meta-analyses of chemotherapy for locally advanced and metastatic pancreatic cancer. J Clin Oncol. 2007;25:2607-2615.

63. Heinemann V, Boeck S, Hinke A, Labianca R, Louvet C. Meta-analysis of randomized trials: evaluation of benefit from gemcitabine-based combination chemotherapy applied in advanced pancreatic cancer. BMC Cancer. 2008;8:82.

64. Belli C, Cereda S, Reni M. Role of taxanes in pancreatic cancer. World J Gastroenterol. 2012;7;18:4457-4465.

65. Okada S, Sakata Y, Matsuno S, et al. Phase II study of docetaxel in patients with metastatic pancreatic cancer: a Japanese cooperative study. Cooperative Group of Docetaxel for Pancreatic Cancer in Japan. Br J Cancer. 1999;80:438-443.

66. Androulakis N, Kourousis C, Dimopoulos MA, et al. Treatment of pancreatic cancer with docetaxel and granulocyte colony-stimulating factor: a multicenter Phase II study. J Clin Oncol. 1999;17: $1779-1785$.

67. Whitehead RP, Jacobson J, Brown TD, Taylor SA, Weiss GR, Macdonald JS. Phase II trial of paclitaxel and granulocyte colony-stimulating factor in patients with pancreatic carcinoma: a Southwest Oncology Group study. J Clin Oncol. 1997;15:2414-2419.

68. Rougier P, Adenis A, Ducreux M, et al. A Phase II study: docetaxel as first-line chemotherapy for advanced pancreatic adenocarcinoma. Eur J Cancer. 2000;36:1016-1025.

69. Schneider BP, Ganjoo KN, Seitz DE, et al. Phase II study of gemcitabine plus docetaxel in advanced pancreatic cancer: a Hoosier Oncology Group study. Oncology. 2003;65:218-223.

70. Sherman WH, Fine RL. Combination gemcitabine and docetaxel therapy in advanced adenocarcinoma of the pancreas. Oncology. 2001;60:316-321.

71. Stathopoulos GP, Mavroudis D, Tsavaris N, et al. Treatment of pancreatic cancer with a combination of docetaxel, gemcitabine and granulocyte colony-stimulating factor: a Phase II study of the Greek Cooperative Group for Pancreatic Cancer. Ann Oncol. 2001;12:101-103.

72. Ryan DP, Kulke MH, Fuchs CS, et al. A Phase II study of gemcitabine and docetaxel in patients with metastatic pancreatic carcinoma. Cancer. 2002;94:97-103.

73. Saif MW, Podoltsev NA, Rubin MS, et al. Phase II clinical trial of paclitaxel loaded polymeric micelle in patients with advanced pancreatic cancer. Cancer Invest. 2010;28:186-194.

74. Löhr JM, Haas SL, Bechstein WO, et al. Cationic liposomal paclitaxel plus gemcitabine or gemcitabine alone in patients with advanced pancreatic cancer: a randomized controlled Phase II trial. Ann Oncol. 2012;23:1214-1222.

75. Gradishar WJ. Albumin-bound paclitaxel: a next-generation taxane Exp Opin Pharmacother. 2006;7:1041-1053.

76. Vogel SM, Minshall RD, Pilipovic M, Tiruppathi C, Malik AB. Albumin uptake and transcytosis in endothelial cells in vivo induced by albumin-binding protein. Am J Physiol Lung Cell Mol Physiol. 2001;281:L1512-L1522.

77. Infante JR, Matsubayashi H, Sato N, et al. Peritumoral fibroblast SPARC expression and patient outcome with resectable pancreatic adenocarcinoma. J Clin Oncol. 2007;25:319-325.

78. Von Hoff DD, Ramanathan RK, Borad MJ, et al. Gemcitabine plus nab-paclitaxel is an active regimen in patients with advanced pancreatic cancer: a Phase I/II trial. J Clin Oncol. 2011;29:4548-4554.

79. Frese KK, Neesse A, Cook N, et al. Nab-Paclitaxel potentiates gemcitabine activity by reducing cytidine deaminase levels in a mouse model of pancreatic cancer. Cancer Discov. 2012;2:260-269.

80. ClincialTrials.Gov. Study to Evaluate Bi-weekly Dosing of Gemcitabine Plus Nab-Paclitaxel to Treat Metastatic Pancreatic Cancer. Available from http://clinicaltrials.gov/ct2/show/NCT01851174. ClinicalTrials.gov Identifier: NCT01851174. Accessed March 21, 2014.

81. Hosein PJ, de Lima Lopes G Jr, Pastorini VH, et al. A Phase II trial of nab-paclitaxel as second-line therapy in patients with advanced pancreatic cancer. Am J Clin Oncol. 2013;36:151-156. 
82. MacKenzie S, Zeh H, McCahill LE, et al. A pilot Phase II multicenter study of nab-paclitaxel (Nab-P) and gemcitabine (G) as preoperative therapy for potentially resectable pancreatic cancer (PC). J Clin Oncol. 2013;31 Suppl:Abstr 4038.

83. Alvarez R, Musteanu M, Garcia-Garcia E, et al. Stromal disrupting effects of nab-paclitaxel in pancreatic cancer. Br J Cancer. 2013;109: 926-933.

84. Kunzmann V, Hartlapp I, Scheurlen M, et al. Sequential neoadjuvant chemotherpy with nab-paclitaxel plus gemcitabine and FOLFIRINOX in locally advanced pancreatic cancer (LAPC): a PILOT study. JClin Oncol. 2013;31 Suppl:Abstr e15193. Available from: http://meetinglibrary.asco. org/content/114422-132. Accessed March 21, 2104.

85. Bradshaw AD, Sage EH. SPARC, a matricellular protein that functions in cellular differentiation and tissue response to injury. J Clin Invest. 2001;107:1049-1054.

86. Arnold SA, Brekken RA. SPARC: a matricellular regulator of tumorigenesis. J Cell Commun Signal. 2009;3:255-273.

87. Guweidhi A, Kleeff J, Adwan H, et al. Osteonectin influences growth and invasion of pancreatic cancer cells. Ann Surg. 2005;242: 224-234.

88. Prenzel KL, Warnecke-Eberz U, Xi H, et al. Significant overexpression of SPARC/osteonectin mRNA in pancreatic cancer compared to cancer of the papilla of Vater. Oncol Rep. 2006;15:1397-1401.

89. Mantoni TS, Schendel RR, Rödel F, et al. Stromal SPARC expression and patient survival after chemoradiation for non-resectable pancreatic adenocarcinoma. Cancer Biol Ther. 2008;7:1806-1815.

90. Delany AM. Matricellular proteins osteopontin and osteonectin/ SPARC in pancreatic carcinoma. Cancer Biol Ther. 2010;10:65-67.

91. Rivera LB, Brekken RA. SPARC promotes pericyte recruitment via inhibition of endoglin-dependent TGF- $\beta 1$ activity. J Cell Biol. 2011;193: 1305-1319.

92. Bradshaw AD. The role of SPARC in extracellular matrix assembly. J Cell Commun Signal. 2009;3:239-246.

93. Watkins G, Douglas-Jones A, Bryce R, Mansel RE, Jiang WJ. Increased levels of SPARC (osteonectin) in human breast cancer tissues and its association with clinical outcomes. Prostaglandins Leukot Essent Fatty Acids. 2005;72:267-272.

94. Koukourakis MI, Giatromanolaki A, Brekken RA, et al. Enhanced expression of SPARC/osteonectin in the tumor-associated stroma of non-small cell lung cancer is correlated with markers of hypoxia/acidity and with poor prognosis of patients. Cancer Res. 2003;63:5376-5380

95. Massi D, Franchi A, Borgognoni L, Reali UM, Santucci M. Osteonectin expression correlates with clinical outcome in thin cutaneous malignant melanomas. Hum Pathol. 1999;30:339-344.

96. Gradishar WJ, Tjulandin S, Davidson N, et al. Phase III trial of nanoparticle albumin-bound paclitaxel compared with polyethylated castor oil-based paclitaxel in women with breast cancer. J Clin Oncol. 2005;23: 7794-7803.

97. Lobo C, Lopes G, Silva O, Gluck S. Paclitaxel albumin-bound particles (Abraxane ${ }^{\mathrm{TM}}$ ) in combination with bevacizumab with or without gemcitabine: early experience at the University of Miami/ Braman Family Breast Cancer Institute. Biomed Pharmacother. 2007;61:531-533.

98. Yardley DA, Daniel BR, Inhorn RC, et al. SPARC microenvironment signature (SMS) analysis of a Phase II trial of neoadjuvant gemcitabine (G), epirubicin (E), and nab-paclitaxel (nab-P) in locally advanced breast cancer (LABC). J Clin Oncol. 2010;28:741 Suppl:Abstr 10574.

99. Socinski MA, Manikhas GM, Stroyakovsky DL, et al. A dose finding study of weekly and every-3-week nab-Paclitaxel followed by carboplatin as first-line therapy in patients with advanced non-small cell lung cancer. J Thorac Oncol. 2010;5:852-861.

100. Socinski MA, Bondarenko I, Karaeva N, et al. Survival results of a randomized, Phase 3 trial of nab-paclitaxel and carboplatin compared with Cremophor-based paclitaxel and carboplatin as first- line therapy in advanced non-small cell lung cancer. J Clin Oncol. 2011;29: 488 Suppl:Abstr 7551.
101. Hersh EM, O’Day SJ, Ribas A, et al. A Phase 2 clinical trial of nab-paclitaxel in previously treated and chemotherapy-naive patients with metastatic melanoma. Cancer. 2010;116:155-163.

102. Desai NP, Trieu V, Hwang LY, Wu R, Soon-Shiong P, Gradishar WJ. Improved effectiveness of nanoparticle albumin-bound (nab) paclitaxel versus polysorbate-based docetaxel in multiple xenografts as a function of HER2 and SPARC status. Anticancer Drugs. 2008;19: 899-909.

103. Shao H, Tang H, Salavaggione OE, et al. Improved response to nab-paclitaxel compared with Cremophor-solubilized paclitaxel is independent of secreted protein acidic and rich in cysteine expression in non-small cell lung cancer. J Thorac Oncol. 2011;6: 998-1005.

104. Desai N, Trieu V, Damascelli B, Soon-Shiong P. SPARC expression correlates with tumor response to albumin-bound paclitaxel in head and neck cancer patients. Transl Oncol. 2009;2:59-64.

105. Neesse A, Frese KK, Chan DS, et al. SPARC independent drug delivery and antitumour effects of nab-paclitaxel in genetically engineered mice. Gut. September 25, 2013. [Epub ahead of print.]

106. ClinicalTrials.Gov. A Study of Vantictumab (OMP-18R5) in Combination With Nab-Paclitaxel and Gemcitabine in Previously Untreated Stage IV Pancreatic Cancer. Available from: http:/clinicaltrials.gov/ ct2/show/NCT02005315. ClinicalTrials.gov Identifier: NCT02005315. Accessed March 21, 2014.

107. ClinicalTrials.Gov. Gemcitabine + Nab-paclitaxel With LDE-225 (Hedgehog Inhibitor) as Neoadjuvant Therapy for Pancreatic Adenocarcinoma. Available from: http://clinicaltrials.gov/ct2/show/ NCT01431794. ClinicalTrials.gov Identifier: NCT01431794. Accessed March 21, 2014

108. ClinicalTrials.Gov. Hedgehog Inhibitors for Metastatic Adenocarcinoma of the Pancreas. Available from: http://clinicaltrials.gov/ct2/ show/NCT01088815. ClinicalTrials.gov Identifier: NCT01088815. Accessed March 21, 2014.

109. ClinicalTrials.Gov. PEGPH20 Plus Nab-Paclitaxel Plus Gemcitabine Compared With Nab-Paclitaxel Plus Gemcitabine in Subjects With Stage IV Untreated Pancreatic Cancer. Available from: http:// clinicaltrials.gov/ct2/show/NCT01839487. ClinicalTrials.gov Identifier: NCT01839487. Accessed March 21, 2014.

110. ClinicalTrials./Gov. Phase 1 Study of PLX7486 as Single Agent and With Gemcitabine Plus Nab-Paclitaxel in Patients With Advanced Solid Tumors. Available from: http://clinicaltrials.gov/ct2/show/ NCT01804530. ClinicalTrials.gov Identifier: NCT01804530. Accessed March 21, 2014

111. ClinicalTrials.Gov. A Phase 1b/2 Study of OMP-59R5 in Combination With Nab-Paclitaxel and Gemcitabine in Subjects With Previously Untreated Stage IV Pancreatic Cancer. Available from: http://clinicaltrials.gov/ct2/show/NCT01647828. ClinicalTrials.Gov identifier: NCT01647828. Accessed March 21, 2104.

112. ClinicalTrials.Gov. Efficacy \& Safety of ODSH (2-0, 3-0 Desulfated Heparin) in Patients With Metastatic Pancreatic Cancer Treated With Gemcitabine \& Abraxane. Available from: http://clinicaltrials.gov/ct2/ show/NCT01461915. ClinicalTrials.gov Identifier: NCT01461915. Accessed March 21, 2014.

113. ClinicalTrials.Gov. M402 in Combination With Nab-Paclitaxel and Gemcitabine in Pancreatic Cancer. Available from: http://clinicaltrials.gov/ct2/show/NCT01621243. ClinicalTrials.gov Identifier: NCT01621243. Accessed March 21, 2014.

114. ClinicalTrials.Gov. Phase II Trial Of Gemcitabine Plus NabPaclitaxel +/- OGX-427 In Patients With Metastatic Pancreatic Cancer. Available from: http://clinicaltrials.gov/ct2/show/ NCT01844817. ClinicalTrials.gov Identifier: NCT01844817. Accessed March 21, 2014.

115. ClinicalTrials.Gov. Safety Study of INCB039110 in Combination With Gemcitabine and Nab-Paclitaxel in Subjects With Advanced Solid Tumors. Available from: http://clinicaltrials.gov/ct2/show/ NCT01858883. ClinicalTrials.gov Identifier: NCT01858883. Accessed March 21, 2014. 
116. ClinicalTrials.Gov. Study to Compare Disease-free Survival of Subjects With Surgically Resected Pancreatic Cancer in the Adjuvant Setting Who Are Taking Nab-paclitaxel in Combination With Gemcitabine vs Gemcitabine Alone. Available from: http:/clinicaltrials.gov/ct2/ show/NCT01964430. ClinicalTrials.gov Identifier: NCT01964430. Accessed March 21, 2014

117. ClinicalTrials.Gov. Randomized Phase II Trial of Pre-Operative Gemcitabine and Nab Paclitacel With or With Out Hydroxychloroquine Available from: http://clinicaltrials.gov/ct2/show/NCT01978184. ClinicalTrials.gov Identifier: NCT01978184. Accessed March 21, 2014 .
118. ClinicalTrials.Gov. Gemcitabine With Abraxane and Other Investigational Therapies in Neoadjuvant Treatment of Pancreatic Adenocarcinoma. Available from: http://clinicaltrials.gov/ct2/show/ NCT01470417. ClinicalTrials.gov Identifier: NCT01470417. Accessed March 21, 2014.

119. ClinicalTrials.Gov. Systemic Therapy and Chemoradiation in Advanced Localised Pancreatic Cancer - 2. Available from: http:// clinicaltrials.gov/ct2/show/NCT02024009. ClinicalTrials.gov Identifier: NCT02024009. Accessed March 21, 2014.

\section{Publish your work in this journal}

Gastrointestinal Cancer: Targets and Therapy is an international, peer-reviewed, open access journal focusing on gastro-intestinal cancer research, identification of therapeutic targets and the optima use of preventative and integrated treatment interventions to achieve improved outcomes, enhanced survival and quality of life for the cancer patient. The manuscript management system is completely online and includes a very quick and fair peer-review system. Visit http://www.dovepress.com/testimonials.php to read real quotes from published authors.

Submit your manuscript here: http://www.dovepress.com/gastro-intestinal-cancer-targets-and-therapy-journal 